\title{
Seeking equilibrium between a social justice and a charity stance towards global learning among Northern Ireland pupils
}

\author{
Linda Clarke* and Lesley Abbott - Ulster University, UK
}

\begin{abstract}
Developing pupils' knowledge and understanding of world poverty and how to reduce it requires building teachers' capacity. With this objective in mind, the UK Global Learning Programme (GLP 2013-18) sought to determine the extent to which a social justice mentality was evident among pupils in Northern Ireland schools in tandem with, or instead of, the prevailing charity mentality. Using a qualitative approach, the research examined their conceptions of, and attitudes towards, social justice and equity, and how they had helped make the world fairer. They understood the causes of inequality and saw the contrast between great wealth and absolute poverty. Their growing motivation to help related mainly to charitable actions, but there was evidence of critical thinking about longer-term implications and a social justice stance.
\end{abstract}

Keywords: global learning, schools, curriculum, social justice mentality, charity mentality

\section{Introduction}

The current polarization of political discourse at local, national and international levels between nationalism and nativism versus globalism and the 'outsider' provides an urgent context for developing children's and young people's knowledge and understanding of these polarities, of the more nuanced interstices, and of the skills and attitudes they might develop in respect of increasingly strident debates about global poverty. Schools must help pupils to make sense of the news and help frame their views, for they are far from immune to current global issues. The celebrity-charged charity appeals on television channels seem designed to tug at their heartstrings but must also engage their informed and rational criticality. This article seeks the views of primary and post-primary pupils on some of the most pressing world issues. It attempts to locate their dispositions in relation to social justice and charitable perspectives.

The article arose from a government-funded project undertaken across the four jurisdictions of the UK, each with the same objectives. The Global Learning Programme (GLP) began in 2013 with a commitment to helping teachers enable pupils at Key Stages 2 and 3 to contribute meaningfully to a globalized world. The Centre for Global Education (CGE) managed the GLP in Northern Ireland and delivered continuing professional development to half of its grant-aided schools (535). It engaged 1,003 teachers in 179 GLP activities over four years. Participating schools received flexible training pathways in global learning, thematic workshops, interactive delivery, resources and guidance grounded in the Northern Ireland curriculum (NIC) and teachers involved 
received certification. A key aim of the GLP was to enable them to encourage pupils to change from a charity to a social justice mentality while recognizing that this would present both practical and pedagogical challenges (Simpson, 2017; Scoffham, 2018).

\section{The context}

It is important to examine the work of the GLP within wider societal debates about global poverty and the public's understanding of development education, and within the positioning of these understandings in the school curriculum. A definition of global learning appears in the Maastricht Declaration as 'education that opens people's eyes and minds to the realities of the world and awakens them to bring about a world of greater justice, equity and human rights for all' (Europe-wide Global Education Congress, 2002: 2). The contrast between transactional and transformative attitudes to poverty is outlined in Darnton and Kirk's (2011: 6) seminal work, which seeks to find better ways of engaging the UK public in global policy by moving the debate from the former, with a charitable focus on the 'powerful giver' and 'grateful receiver', towards the latter, stressing more complex understandings. Darnton and Kirk (2011) also recognized the role played by a zeitgeist characterized by increasing levels of consumerism and individualism. Crucially, however, they acknowledge the role of charitable non-governmental organizations in the development sector, including major celebrity-endorsed events like Band Aid, in producing this emphasis on charitable giving.

Arguably, pupils are even more likely to be influenced by famous people - what Bryan and Bracken (2011) term the phenomenon of celebrity activists - all of which may have redoubled this impact on young minds. They refer to these individuals as enhancing 'their sense of themselves and the reputation of the country they represent, with insufficient attention to their own participation in relations of domination' (Bryan and Bracken, 2011: 73). Moreover, Lim and Moufahim (2015: 537, 538) suggest that 'the spectacularized suffering of celebrities as they undertake journeys of adventure, fear and deprivation' results in the real questions being trivialized, and the real suffering of 'distant others' almost forgotten. However, Gorard (2011) stressed that teachers in schools have a noted effect on what he calls pupils' typically powerful sense of justice. Similarly, Worden and Smith (2017: 392) refer to the 'pivotal role ... [of these] critical actors'.

Like Darnton and Kirk (2011), Simpson (2017: 90) defines a charity mentality as one typified by a focus on 'the global North's responsibility towards the global South ... [with] those in the North in a position of power, creating a seemingly kind and benevolent master but a master nonetheless'. A social justice mindset, however, through critical reflection on inequalities near and far, has the potential to remove any perception of power, challenge stereotypes and foster a sense of equality that can bring about positive change.

The challenge of defining a social justice mentality is that it is not a 'fixed' concept but rather, as Bourn (2014) suggests, it is a result of several influences and ultimately depends on an individual's perspective. That perspective very much depends on political views on the causes and manifestations of inequities in the distributions of goods, opportunities and rights at local, national and international scales. Simpson (2017: 91) believes, however, that fostering a social justice mentality 'could be considered a commitment to equality - a developed critical or independent thinking that results in ethical action'. 
Hackman (2005: 103) advocates that social justice could be used as a 'pedagogical lens' for learning, suggesting that it needs more significance within education as a whole. Bryan et al. (2009: 31) imply that the importance of the role of social justice has been amplified with modern globalization and the realization that many issues are indeed global ones that 'transcend borders'. If this is the case, the role of educators in encouraging young people to develop a social justice mentality is more significant than ever, as is the need to overcome a charity mentality and see beyond our colonial psyche to engender a truly equal global society.

\section{Global learning in Northern Ireland}

The GLP also brought a new nomenclature to this area of the NIC and bringing global learning into it was a major task (CCEA, 2007a,b), one which met both with some discontinuities but, simultaneously, many synergies. The work of the GLP here lies within the revised Northern Ireland Curriculum's distinctive approaches to both content (less prescriptive than in previous iterations) and pedagogy (with a particular emphasis on criticality and active learning), that is, 'to empower young people to develop their potential and to make informed and responsible decisions throughout their lives' (UKaid, 2010: 9). The GLP showed further consistency with the curriculum in viewing global learning as located in all subjects, in cross-curricular thematic units and whole-school initiatives, and in connected learning provision for the specified crosscurricular theme within the NIC which is framed as (Local and) Global Citizenship. Therefore, it sought to find a place in a curriculum where the terminology of its most relevant component was out of step with that of the programme itself, and where no new revision is forthcoming. Worden and Smith (2017) noted two further key issues, namely, finding space and securing status for local and global citizenship in the already crowded NIC where traditional academic subjects such as history and geography (which each include substantial overlap with the local and global citizenship curriculum, respectively) are given precedence.

Just as the public could be forgiven for being confused at the volte-face that is leading the development sector and which eschews their previous enthusiasm for a charity approach, Northern Ireland's teachers could, similarly, be forgiven for questioning how local and global citizenship within the statutory curriculum had been supplanted by 'global learning'. Bourn (2014) argues that using different terms can result in the focus and purpose of the concept being unclear, an issue continuing to spark debate. Thus, the GLP team had an immediate task: to explain this change and then justify, demonstrate and resource the latest stance on development education, and to do so across the curriculum - not just in geography where teachers already have very considerable expertise and resources, but also within the newly specified active learning pedagogical approaches. Hopkin (2018: 4), in his report for the Geographical Association, makes the distinctive and highly relevant expertise of geographers clear:

Geography has always been the world subject. Both in the school curriculum and as a way of thinking, learning about the world is inextricably bound up with the emergence of the discipline of geography. No other part of the curriculum has such a clear global perspective... Understanding the global is fundamental to learning and achievement in geography, just as learning geography is essential to understanding the global.

Further, it might be argued that geographers' capability means that this single subject is the best, although not the sole, home for global learning and that, in the absence 
of teacher competence beyond geography, there is a risk of diluting the complexities of these matters. Interdisciplinarity works best where it is underpinned by inherently strong disciplinary knowledge. In response, the GLP sought to support teachers right across the curriculum to develop in children and young people an awareness of 'the impact their own actions can have on others', adding that 'a holistic approach to global learning equips [pupils] with the essential knowledge, skills, attitudes and dispositions that will enable them to realize their potential and make a contribution to a fair, sustainable world' (CGE, 2018: 6).

Fortuitously, the GLP found a ready-made fit in the unique learning context across all key stages in Northern Ireland due to the strong pedagogical emphasis by the Council for the Curriculum, Examinations and Assessment (CCEA) on active learning approaches, collaborative learning and building personal skills. This approach is important because it links closely with the GLP notion of pupils becoming genuinely involved. The revised NIC presented a smaller, less detailed content base to teachers, but it did require these approaches, and the smaller amount of specified curricular content provided the time to implement them in classrooms in both the primary and post-primary sectors. There is also some overlap with the key concepts of the global dimension including inter alia global citizenship, conflict resolution, diversity, human rights, social justice and sustainable development (DfES, 2005). As well, Nussbaum (1994, n.p.) believes that: 'We should recognize humanity wherever it occurs, and give its fundamental ingredients, reason and moral capacity, our first allegiance and respect.' Further, the NIC explores the connections between the local and the global, the building of knowledge and understanding, as well as the development of skills and attitudes. These elements, too, and their underpinning Freirean rationale (Freire, 1996) linking education and politics, chime very well with global learning's essential focus on encouraging the development of pupil solidarity with those facing the realities presented by global inequity.

\section{Challenges for teachers in schools}

Such work in schools, however, faces obstacles. Pedagogically, there is 'the complexity of the very concept' (Hunt and King, 2015: 29), how to 'navigate the ambiguities in global learning, acknowledge the role of emotions and circumnavigate the legacy of colonialism' (Scoffham, 2018: 140). Practically, there is a lack of dedicated time for 'substantive engagement' (Bryan and Bracken, 2011: 38), no dedicated funding (CGE, 2018) and, in post-primary schools, a dominant charity, not a human rightsbased, perspective (McCarthy and Gannon, 2016). There are competing demands and priorities within the curriculum, timetable restrictions, limited capacity and difficulties persuading some colleagues to embed global learning in their teaching (CGE, 2018; Ferguson-Patrick et al., 2018). Further, there is time-limited training for educators (Simpson, 2017). Therefore, as Ferguson-Patrick et al. (2018: 197) note, 'teaching global education, although highly valuable and definitely of great value in the twenty-first century, is not easy to implement in such an educational context.' Of course, ongoing support from trainers would be ideal but not pragmatic. Additionally, assessment of global learning presents unique challenges (IDEA, 2013; Scoffham, 2018) whereby it is difficult to identify progression, and Hunt and King (2015: 28) speak of discerning 'actual, rather than assumed, change'. 


\section{Aim and objectives}

The overall aim of the wider study conducted in Northern Ireland was to assess the impact of the GLP training over three years in meeting its target of enhancing global learning practice in half of its primary, post-primary and special schools. The main objectives were, first, to examine through quantitative and qualitative methods (surveys and interviews) the extent to which the programme strengthened teachers' knowledge of global learning and their implementation of it in classrooms; and, second, to identify progression over three years in Key Stages 2 and 3 primary and post-primary pupils' conceptualization and awareness of global learning issues, as well as their skills and dispositions (see Table 1). This article draws on qualitative pupil data gathered in six schools. Specifically, it sought to determine whether a social justice mentality existed alongside the prevailing charity mentality. The wider study benefited from the mixed methods approach (Burke Johnson and Onwuegbuzie, 2004), which, as Denscombe (2008: 272) explains, is 'a means of avoiding biases intrinsic to singlemethod approaches'. Seeking 'different actors' viewpoints' also helped increase validity (Cohen et al., 2007: 141).

\section{Methodology}

\section{Interview schools}

The six interview schools were drawn from the first 75 registering with the CGE for the 2014-15 training programme, the single criterion for inclusion being the nominated lead teachers' attendance at the GLP. A convenience sample was selected using the variables of sector and management type with a geographical spread across Northern Ireland's five education sub-regions (local education authorities). There were three primary (P) and three post-primary (PP) schools with, in each phase, a controlled (mainly Protestant) (C), a maintained (almost exclusively Catholic) (M) and an integrated school (educating Catholic and Protestant pupils and those of other religions or none) (I) (NIClE, 1991).

\section{Pupil interviews}

Small-group interviews were conducted using circle time to which primary children in Key Stage 2 were accustomed (Mosley, 1996; Miller and Moran, 2007), a research tool previously employed by Clarke and Abbott (2016). Although not used in the postprimary phase, it was still familiar to Key Stage 3 pupils (Table 1).

Table 1: Years and ages for compulsory education (Northern Ireland) at Key

\section{Stages 2 and 3}

\begin{tabular}{lll}
\hline Key Stage & Years & Ages \\
\hline 2 (primary) & $5,6,7$ & $8-11$ \\
3 (post-primary) & $8,9,10$ & $11-14$ \\
\hline
\end{tabular}

Source: DfES, 2005

Circle time allows each pupil to contribute to all questions, there are no 'put downs', and they need not talk about a topic they find sensitive, thus ensuring their emotional safety (Mellor and Munn, 2000). Children may also be less intimidated talking within a peer group (Lewis, 1992: 416). There was awareness of how long children may take 
to answer (Kellet and Ding, 2004), and leading was avoided to ensure reliability of responses (Lewis, 2002). Group size depended on pupil numbers choosing to participate, although it was to be neither too large nor too small (Lewis, 1992). Each interview lasted approximately 20 minutes.

Thematic analysis from verbatim transcriptions of the audio-recorded group interviews consisted of identifying themes and sub-themes showing consensus or emerging patterns. It included selected extracts from the 40 Primary 7 and 26 Year 10 pupils' responses in Year 3 to give a 'detailed and nuanced account' (Braun and Clarke, 2006: 83) indicating sector and management type. Any overall growth and greater depth of outlook were noted in pupils' understanding of, and attitudes towards, the key issues to see if they had met Oxfam's (2006) examples of progression for Key Stages 2 and 3.

\section{Pupil profile}

Group composition in the six cohorts was inconsistent as different numbers of pupils agreed to participate over the three years, giving a total of 217 present at group interviews during the project, although this figure represented overlap. Concerning school sector in Year 3, 60.61 per cent (40) were primary, and 39.39 per cent (26) postprimary. Over 60 per cent were girls in each year.

To explain the overlap and clarify the 217 figure, 31.64 per cent of pupils said they had taken part in Year 1 interviews (25: 16P, 9PP) when asked in Year 2. In Year 3, 53.73 per cent had done so in Year 2 (36: 26P, 10PP). Hence, responses were not matched to pupils over time, and only overall evidence of progression was reported. The study was not longitudinal in respect of the data as it did not develop as an entity and results must be cautiously interpreted.

\section{Ethical issues}

Alderson (2005: 102) states that 'many ethical questions arise at each stage of a project, especially in research with fairly powerless groups such as children', but the desirability of obtaining their views is well documented (Fielding and Bragg, 2003) and they are indeed able to speak for themselves (Barker and Weller, 2003). Full ethical approval was obtained from the University's Research Ethics Committee, adhering closely to BERA's (2011) guidelines. As well as school permission, parental consent, pupil assent, assurances of confidentiality, anonymity and privacy, the pupils were asked prior to interview for what Lewis (2002) calls explicit continuation of assent to allow a genuine right to withdraw (see also Nutbrown and Clough, 2009). Rapport was established and topics were re-stated. The findings are reported below.

\section{Findings}

\section{Knowledge and understanding of social justice and equity}

In an open-ended question, pupils identified what was important for 'a good life'. Year 3 answers closely reflected the previous two years with essential physical needs again prioritized (shelter, food, water, clothing), now also including children's rights and having family, parents and friends - 'Someone they can talk to' $(P, C)$. There was more mature recognition by two Year 3 pupils that an effective government was needed as well as safety and peace, both threatened by war: 'Safe environment ... there might 
be danger like bombs in Syria, so a safe, child-friendly environment' (P, M); 'Just stop looking in the past and look forward' $(P, I)$.

All but two primary pupils agreed that not everyone in Northern Ireland had these essentials - 'Absolutely not' $(\mathrm{P}, \mathrm{I})$. Initial reasons were lack of money, but by Year 2 awareness of the repercussions became evident, with homelessness and unemployment the predominant social problems: 'There's loads of homeless people around Belfast and other cities' $(\mathrm{P}, \mathrm{l})$; 'People don't have enough money ... not enough jobs' (P, M). In Year 3, some primary children gave more insightful reasons for their answers, speaking with concern about extreme poverty having witnessed people begging - 'Not everyone has a home ... and they're begging for food and water' $(P, C)$. Some thought unwise spending and substance abuse caused hardship, describing the implications of the latter for children - 'Some children are getting looked after because their parents aren't looking after them. They could be on drugs' $(P, M)$. One child underlined the need for compassion - 'We need to keep social because ... a lot of bad things can happen if we're antisocial to humans' $(P, I)$.

Post-primary pupils in Year 3 also revealed growing knowledge about the main causes of poverty close to home and could see the potential damage. For them, it arose principally from substance abuse - 'If they get addicted to drugs, smoking and alcohol and spend all their money' (PP, M) and from unemployment, debt, a disadvantaged family background and a lack of education that could cause 'a ripple effect ... then it puts them in a worse situation' (PP, I). Unfairness was exemplified by discrimination, either racial or because of sexual orientation: 'Some people over here might not accept you for being from a different place' (PP, C); 'Maybe a young person comes out ... a certain sexuality and their parents might not agree to it, and they might throw the kid out of the house' (PP, C).

Next, the post-primary pupils were asked how people's lives in Northern Ireland could improve, mainly suggesting charity work, fundraising and donating food and clothes. However, they also now saw the wider picture in terms of immediate and longer-term needs, with conviction that the poor and homeless deserved financial aid from the government, help with education, advice on dealing with substance abuse and its repercussions and encouragement to be part of a support group: 'Notice them' $(\mathrm{PP}, \mathrm{I})$; 'The government should help out' (PP, M); 'Educate them on different things, like if they're addicted to something that was losing them money, you could help them get off it' (PP, I). They firmly believed they themselves and charities were collectively responsible: 'Give away our clothes and stuff' (PP, M); 'Charity work' (PP, I); 'We can do fundraisers' (PP, I).

As to why not everyone elsewhere in the world had their essential needs met, pupils were emphatic that not everyone elsewhere in the world had their essential needs met. Primary children in Year 2 blamed environmental conditions - Natural disasters, like earthquakes, volcanoes' $(P, M)$ - then in Year 3 went further and pointed to foreign governments failing to give financial aid: 'In some countries, the government takes everything from them' $(\mathrm{P}, \mathrm{C}) ;{ }^{\prime}$... they can't grow any food and they can either die of starvation or dehydration' (P, M). However, a need was reiterated for charitable support: 'There's a ton of poor countries that are dying right now, such as Africa [sic] ... needing charities to try and keep stable' $(\mathrm{P}, \mathrm{I})$. All this appeared to indicate a measure of progression in primary pupils' gradually deepening knowledge of global inequality, albeit a continuing charity mentality while acknowledging their own role.

Post-primary pupils also saw the main causes of global poverty as no food or clean water, climate change, drought and natural disasters. By Year 3, they saw no chance of trade relations, fair remuneration or proper working conditions - 'In poor 
countries, they can't have alliance with richer countries because they've nothing to offer to them' (PP, C). Cited again were corrupt governments spending money on war instead of education and charitable donations not reaching their destination. Those in need had no voice, no opportunities and endured exploitation - 'People suffering in a war-based country that hasn't much access to food and water' (PP, M); 'They need education, qualifications' (PP, C); 'Most people can't get jobs and even if they do ... the pay isn't good enough' (PP, M).

To remedy this, older pupils declared that the rich should help the poor and be taxed more highly although 'they probably wouldn't be happy about it' (PP, I), resources should reach those in need and there should be better rights for workers. There was increasing understanding of the scale and effect of global poverty, including the risks for the most vulnerable and the obstacles they faced in improving their lives, from environmental conditions outside their control to receiving practical help from governments: 'They don't have food and their governments probably spent it on something they don't really need ... bombs and guns' (PP, M); 'You see these adverts and they want you to give money because children are not getting the nutrition they need' (PP, C); 'Some are far too wee and they might not survive' (PP, C).

Primary children saw the main differences in the lives of people with and without the essentials as few life chances for the latter unless donations were forthcoming or a charity intervened. Conversely, those who had everything took it for granted. In Year 2, they painted quite vivid pictures of extreme deprivation and could contrast the lives of those for whom life was fair or unfair, but by Year 3 had a firmer grasp of the harsh realities and spelled out the drastic consequences: 'The people that don't have everything they need ... they don't have food, they don't have shelter, they don't have someone to help them and they don't have medication' ( $\mathrm{P}, \mathrm{I})$; 'All we do is walk to a tap to fill the glass, and some people have to walk miles to get some water that could kill them in the end' $(P, M)$.

The principal effect of poverty in Northern Ireland was said by most postprimary pupils in Year 3 to be poor mental health. This was also raised in Year 2 but now exemplified more fully as depression, a sense of worthlessness and isolation. Homelessness, too, could mean sleeping rough with dire outcomes like ill health or turning to crime. There could be prejudice and unfair suspicion from society:

Sometimes when they're poor ... they might be living on the street. Even if they do get money and maybe they don't want to spend it on alcohol and actually do want to help their family, sometimes shopkeepers won't let them in because they think they're going to steal things. They just automatically assume ... it's a kind of prejudice ... they're viewed a lot differently in society ... actually not good. (PP, M)

Hence, all pupils showed believable sensitivity about inequality within and between their own and other societies - 'You take for granted your own bed ... heating your house' (PP, C). They could highlight the causes and effects of poverty as well as ways to eradicate it which remained, however, to a great extent conditional upon charity work and fundraising. Nevertheless, they had begun to define their own role as local and global citizens.

\section{Skills, attitudes and dispositions related to social justice and equity}

There was almost complete consensus in both phases about the unfairness of the stark contrasts between the very rich and the very poor. Pupils readily typified the former: 'They're not using [their wealth] for major problems in other countries. They just end 
up spending it on cars [and] clothes' (PP, C); 'Definitely not fair on people who don't even get the chance to get an education or healthcare' (PP, I). Just two post-primary pupils argued that if people had worked for their money, they deserved it.

Concerning pupils' attitudes towards inequity in Years 1 and 2, these were entirely negative. Sadness predominated, although anger (annoyance, disgust, irritation) emerged in Year 2 and became the largest single category by Year 3, almost equalling all other negative emotions combined (feeling bad, horrible, guilty, sorry, greedy, selfish, uncomfortable, 'sick to the stomach'): 'Puzzled and angry' (P, M); 'A bit powerless because there's so much war and it takes over everything' $(P, M)$. There was increasing concern for others over the three years and the capacity to make articulate, sometimes graphic, comments with clear motivation to help - 'If I had a million pounds to spend and there were two homeless people, I'd give both of them $f 250,000$ each, just to kickstart them, and I would give to charity' $(P, I)$ :

It's disgusting what rich people do to homeless people ... This guy was caught on video, a rich teenager and he saw this homeless guy with a sign saying, 'Please help, my daughter is about to die of hunger', and do you know what he did? He walked over and said, 'Filthy homeless man, and spat in his face'. $(P, I)$

Post-primary views were similar, often focusing on the need for a more proactive stance: 'There's more that people can do to help others' (PP, M); 'It makes me angry because it's been happening for years and we haven't fixed it yet' (PP, C); 'We're in the top half of the richest countries, and we're not doing enough about making it more fair' (PP, I).

Pupils in both phases had tried to make the world fairer, almost exclusively through charitable actions within and beyond school: 'Fundraising in school, like sponsored walks, petitions and bun sales, but also outside school' (PP, I); 'In the shop I would see if there's one of those wee cans for charity and give them my spare change' $(P, M)$; 'I am from a different country ... I give money to the school and we done [sic] a [charity] collection' $(P, I)$; 'Outside school I'm in a youth club. You go and help the homeless, like, feed them and ... talk to them' (PP, M). They could also recognize the purpose of fundraising: 'Our school raised money to get a little boy in Africa into school and get him an education' (PP, C); 'Give money to charities so they can build a water pump' (PP, C).

The influence of family was also very apparent. The families of two pupils had, respectively, adopted a child in a Third World country and signed the petition for Amnesty International 'to help people in countries who need it' (PP, I). However, two primary pupils stated that they had not helped because their parents did not give to charity, one expressing regret: 'I'm sad to say this, but no, because my parents never, ever let me give to charities. I don't know why' $(P, I)$.

Having helped the less fortunate, locally and sometimes globally, pupils' feelings were highly positive, happy or proud in almost equal measure: 'Happy for doing it, but disgusted that millions wouldn't care' $(\mathrm{P}, \mathrm{I})$; 'There's still a lot more that we and other people could do to help' (PP, I). Some felt like 'nicer people': 'It makes you feel good about yourself because you're helping lots of people you don't know' (PP, M), although one primary child said giving was not to make oneself feel better. A few felt helpless or sorry, causing them to 'think about helping others' $(P, M)$. For a fairer world, pupils in both sectors again fluently stressed the need for governments to provide more accessible homeless shelters, enlist more volunteers to build houses, hospitals and schools in poorer countries and train staff to work in them, to sustain the environment and to make the very rich more aware of the importance of giving. 
Overall by Year 3, concerning skills, attitudes and dispositions, while partly resembling Year 2 findings, pupils seemed more insightful, demonstrated empathy (a genuine connection), compassion and a nascent sense of responsibility towards those in need locally and globally, and the beginnings of a social justice mentality. They recognized unfairness well beyond classroom and school level, and began to challenge events and attitudes perpetuating it. Primary children could understand injustice and proposed logical reasons to eradicate it, feeling proud of their own actions. Similarly, post-primary pupils were sensitive to the plight of others, one perceptively acknowledging the limited effect of financial help, a stance more reflective of a social justice mentality - 'I've done some stuff, like given to charity in school, but I haven't done anything that is really, really going to impact on their lives' (PP, M).

\section{Knowledge and understanding of power and governance}

In all three years, most pupils saw it as everyone's responsibility to make the world fairer, demonstrating the emergence of a social conscience and believing that charities, the media, governments and retailers had a role. Charities could use formal education as a vehicle (workshops), donate basic needs to the homeless, divide resources fairly, arrange fundraisers and raise awareness through television appeals. The media should show where help was most needed and how to give it, and almost shock the public - '[They] should give the truth ... it's absolutely horrible, disgusting that people don't have as much as us ... I think that gets the point around more' (P, C). Television channels should focus on charities and what is important - 'Take a bit of that gossip time' $(P, I)$. Governments could help financially, reduce taxes and not spend money on war, 'things like guns, bombs, ammo' (PP, M). Supermarkets and shops could donate goods to the poor, support Fair Trade products and ensure their workers are treated fairly.

Thus, while pupils in Years 2 and 3 proposed broadly similar measures to be taken by different bodies, those in Year 3 offered numerous other suggestions, a few shown above. As elsewhere, they now appeared better informed about efforts to help. Concern for achieving a fairer, more sustainable world were evident and, for themselves, a continuing emphasis on doing and giving.

\section{Awareness of global learning}

Most pupils learned about world events from various sources. For primary children in Year 3, it was through television news, parents and friends, just one child referring to school as a source. Post-primary pupils, however, specified school subjects, mainly geography and religious education (RE), some mentioning learning for life and work (LLW) and dance, just one going further - 'There was a time where all our subjects were doing something with poverty' (PP, M). Special assemblies and school events (both charity-related) were cited, with comparable mention of social media (largely post-primary pupils), the newspapers and TV advertisements (both sectors): 'News, Internet, friends, family, strangers on the street, everywhere in the world there's a TV or a radio, and you're going to hear something that you don't necessarily want to hear'

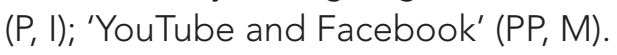

Finally, in Year 3 work for primary pupils on global inequality was through thematic units and topics, learning about the purpose of fundraising events - 'We had Fair Trade day or week and a coffee morning' $(P, C)$. By Year 3, such links were through the study of novels which had clearly affected their perceptions of poverty and its consequences past and present - 'We did lots on workhouses and diseases, and what 
it was like in Victorian times, but then we learned that diseases are still going about in Africa today' $(P, M)$.

Recent post-primary learning about global learning, however, was again subjectbased centring on geography, for example work on sustainability and saving resources. Most understood serious global problems as they affected the most vulnerable who had no rights, especially the young 'like what happens in India and we watched a programme [that] showed you a factory where girls were working. They were getting abuse and bad working conditions' (PP, M); 'In LLW, we did a topic on street children which I found worried me the most because it was talking about children, whereas in geography it was mostly like you were seeing older people that were poor' (PP, M).

Some suggestions were made for possible short- and longer-term solutions, showing pupils' capacity to look beyond the here and now: 'In geography we learned about help we can give to these countries like long-term aid and short-term aid like Live Aid, Children in Need' (PP, M); 'Long term would be factories and training people and setting up schools. Short term would be for clothes and tents and stuff' (PP, C).

\section{Discussion}

Pupils showed convincing sensitivity about inequality within and between their own and other societies and identified the causes and outcomes of poverty in addition to the complex, long-term challenges hindering its eradication. Although still predominantly proposing charity work and fundraising, they began to exhibit a fledgling understanding of social justice.

After three years their views and dispositions, while resembling earlier findings, were more insightful and critical, seeming to demonstrate empathy, compassion and an incipient sense of responsibility towards those in need worldwide - 'the capacity to identify with others' (Khazem, 2018: 131). In their rudimentary way, they had begun to challenge events perpetuating unfairness, and were proud of their efforts to help. Perceptively, one primary child emphasized that it was not about making oneself feel better (Bryan and Bracken, 2011), and a post-primary pupil referred to the limited effect of financial help to those in need through a charity stance alone, again a viewpoint more reflective of an early social justice mentality.

While Years 2 and 3 pupils proposed similar measures to be taken by different bodies, with the role of charities, governments, the media and retailers threaded throughout the data, Year 3 pupils offered more ideas, appearing better informed and more persuaded about the need for global fairness. There remained a continuing, collective drive to do and to give through relatable, tangible activities.

Wider understanding of the implications of world problems seemed evident in Year 3, with greater emphasis on potential outcomes and awareness of shortand longer-term solutions, all characteristic of increased knowledge and deeper thought. Pupils in all six schools learned about global learning through thematic units, discrete subjects and charitable events within and beyond school, all instigated and implemented by teachers with their noted influence on children (Gorard, 2011; Worden and Smith, 2017). However, there were numerous outside sources - families, friends, social media - and the part played by celebrities (Lim and Moufahim, 2015), mostly charity-related. Hunt (2012: 19) warns that 'direct causal links of the impact of global learning on children might be difficult to gauge as [they] have a range of influences, many external to school', a particular challenge for teachers. Additionally, these impacts may only emerge over time (Tanswell, 2011). 
An optimistic assessment might be that there remains an imbalance between a social justice and a charity mentality. Although a charity stance is often a starting point (Bourn, 2014), Simpson (2017: 92) emphasizes that 'values should be challenged and questioned, perhaps unlearnt and reformed, and that this critical reflective process is ongoing'. The importance of pupils developing a critical lens on global learning remains crucial. Genuine, gradual progress can be made as continued efforts by schools and teachers enable children and young people to widen their 'circle of concern', to use Kofi Annan's term, and 'be able to embrace the fate of distant peoples' (UN, 2002).

\section{Conclusions}

This article provides a window into the difficulties for teachers and the GLP team as they deliver training for educators, but writ large throughout the pupils' views is evidence of their keenly felt desire to understand and, particularly, to help.

The key hurdles for global learning in Northern Ireland schools are both practical - finding space in a crowded curriculum (see also Ferguson-Patrick et al., 2018), and professional - building genuine teacher expertise, criticality, enthusiasm, personal ownership and professional leadership, which must underpin all global learning teaching if such complex learning is to be effective. This echoes Simpson (2017: 93) who cautions that 'it might be agreed that we cannot approach the subject of injustice too lightly nor employ emotive reactors to engage in the issue', going on to suggest that 'we need, instead, a keener approach to engage learners' skills and to empower and enable educators to think critically both professionally and personally'.

Potentially, global learning providers might offer an ongoing online forum for teachers and cluster groups could be formed at the schools' discretion to share ideas and positive outcomes, an approach concomitant with the Department of Education's Strategy for Teacher Professional Learning (DENI, 2015), while continued efforts by teachers in classrooms would cascade and embed the global dimension. Although the sustainability of short-term projects is challenging, especially where the statutory curriculum does not use global learning parlance, there is always a place for global learning within academic subjects, notably geography.

It seems that both a charitable disposition and a social justice orientation (of varying levels of complexity) already coexist in pupils' minds and lives at an almost visceral level, judging by their heartfelt, thoughtful words. This powerful crossfertilization will need careful nurture to be sustained in the face of the challenges that are increasingly prevalent within a globalized world even on this fragment of an island.

\section{Notes on contributors}

Linda Clarke was born in Brooklyn, New York, moving to Northern Ireland in early childhood. She qualified as a teacher in 1983 and was a geography teacher and Head of Department for 15 years. She was appointed as Lecturer in Education at Ulster University in 2001 and served as Head of the School of Education at Ulster from 2009 to 2013. Linda's key research interests lie in teacher education and pedagogical practice, particularly around both education technology and global learning. She is currently Research Director for Education at Ulster and is a member of the Research Excellence Framework (REF) 2021 Sub-Panel for Education.

Lesley Abbott is Honorary Fellow of Ulster University and Educational Research Consultant, previously working as a research fellow at Ulster, including in the UNESCO Centre. She was awarded the Brian Simon Educational Research Fellowship in 2006-7 
by the British Educational Research Association. Her research interests include inclusive education; Northern Ireland integrated schools; children's use of tablet technology; teacher education and the needs of student teachers; and the professional needs of learning support assistants.

\section{References}

Alderson, P. (2005) 'Ethics'. In Fraser, S., Lewis, V., Ding, S., Kellett, M. and Robinson, C. (eds) Doing Research with Children and Young People. London: SAGE Publications, 97-112.

Barker, J. and Weller, S. (2003) '"Is it fun?": Developing children centred research methods'. International Journal of Sociology and Social Policy, 23 (1-2), 33-58.

BERA (British Educational Research Association) (2011) Ethical Guidelines for Educational Research. London: British Educational Research Association.

Bourn, D. (2014) The Theory and Practice of Global Learning (DERC Research Paper 11 for the Global Learning Programme). London: Development Education Research Centre.

Braun, V. and Clarke, V. (2006) 'Using thematic analysis in psychology'. Qualitative Research in Psychology, 3 (2), 77-101.

Bryan, A. and Bracken, M. (2011) Learning to Read the World? Teaching and learning about global citizenship and international development in post-primary schools. Dublin: Irish Aid.

Bryan, A., Clarke, M. and Drudy, S. (2009) 'A study of student teachers' perspectives on social justice and development education'. Online. www.ubuntu.ie/media/bryan-clarke-drudy-2009.pdf (accessed 20 May 2019).

Burke Johnson, R. and Onwuegbuzie, A.J. (2004) 'Mixed methods research: A research paradigm whose time has come'. Educational Researcher, 33 (7), 14-26.

CCEA (Council for the Curriculum, Examinations and Assessment) (2007a) The Northern Ireland Curriculum: Primary. Belfast: Council for the Curriculum, Examinations and Assessment.

CCEA (Council for the Curriculum, Examinations and Assessment) (2007b) The Statutory Curriculum at Key Stage 3. Rationale and Detail. Belfast: Council for the Curriculum, Examinations and Assessment.

CGE (Centre for Global Education) (2018) Research into the Impact of the Global Learning Programme in Northern Ireland 2015-2017. Belfast: Centre for Global Education.

Clarke, L. and Abbott, L. (2016) 'Young pupils', their teacher's and classroom assistants' experiences of iPads in a Northern Ireland school: "Four and five years old, who would have thought they could do that?"'. British Journal of Educational Technology, 47 (6), 1051-64.

Cohen, L., Manion, L. and Morrison, K. (2007) Research Methods in Education. 6th ed. London: Routledge.

Darnton, A. and Kirk, M. (2011) Finding Frames: New ways to engage the UK public in global poverty. London: Bond.

DENI (Department of Education Northern Ireland) (2015) Learning Leaders: A strategy for teacher professional learning. Bangor: Department of Education Northern Ireland.

Denscombe, M. (2008) 'Communities of practice: A research paradigm for the mixed methods approach'. Journal of Mixed Methods Research, 2 (3), 270-83.

DfES (Department for Education and Skills) (2005) Putting the World into World-Class Education: An international strategy for education, skills and children's services. Nottingham: Department for Education and Skills.

Europe-wide Global Education Congress (2002) 'Maastricht Global Education Declaration'. Online. https://rm.coe.int/168070e540 (accessed 8 February 2019).

Ferguson-Patrick, K., Reynolds, R. and Macqueen, S. (2018) 'Integrating curriculum: A case study of teaching global education'. European Journal of Teacher Education, 41 (2), 187-201.

Fielding, M. and Bragg, S. (2003) Students as Researchers: Making a difference. Cambridge: Pearson Publishing.

Freire, P. (1996) Pedagogy of the Oppressed. Trans. Ramos, M.B. London: Penguin Books.

Gorard, S. (2011) 'The potential determinants of young people's sense of justice: An international study'. British Journal of Sociology of Education, 32 (1), 35-52.

Hackman, H.W. (2005) 'Five essential components for social justice education'. Equity and Excellence in Education, 38 (2), 103-9.

Hopkin, J. (2018) Geography and Global Learning: A national research report by the Geographical Association. Sheffield: Geographical Association. Online. https://tinyurl.com/y54sgwjh (accessed 17 August 2019). 
Hunt, F. (2012) Global Learning in Primary Schools in England: Practices and impacts (DERC Research Paper 9). London: Development Education Research Centre.

Hunt, F. and King, R.P. (2015) Supporting Whole School Approaches to Global Learning: Focusing learning and mapping impact (DERC Research Paper 13 for the Global Learning Programme). London: Development Education Research Centre.

IDEA (Irish Development Education Association) (2013) Good Practice Guidelines for Development Education in Schools. Dublin: Irish Development Education Association.

Kellett, M. and Ding, S. (2004) 'Middle childhood'. In Fraser, S., Lewis, V., Ding, S., Kellett, M. and Robinson, C. (eds) Doing Research with Children and Young People. London: SAGE Publications, 161-74.

Khazem, D. (2018) 'Critical realist approaches to global learning: A focus on education for sustainability'. International Journal of Development Education and Global Learning, $10(2), 125-34$.

Lewis, A. (1992) 'Group child interviews as a research tool'. British Educational Research Journal, $18(4), 413-21$.

Lewis, A. (2002) 'Accessing, through research interviews, the views of children with difficulties in learning'. Support for Learning, 17 (3), 110-16.

Lim, M. and Moufahim, M. (2015) 'The spectacularization of suffering: An analysis of the use of celebrities in "Comic Relief" UK's charity fundraising campaigns'. Journal of Marketing Management, 31 (5-6), 525-45.

McCarthy, M. and Gannon, M. (2016) 'Embedding development education in post-primary teaching and learning: Lessons from WorldWise Global Schools'. Policy and Practice: A Development Education Review, 23, 102-23.

Mellor, A. and Munn, P. (2000) 'Information on Circle Time'. Online. http://antibullying.net/ circletime.htm (accessed 11 February 2019).

Miller, D. and Moran, T. (2007) 'Theory and practice in self-esteem enhancement: Circle-Time and efficacy-based approaches - a controlled evaluation'. Teachers and Teaching: Theory and Practice, 13 (6), 601-15.

Mosley, J. (1996) Quality Circle Time in the Primary Classroom. Wisbech: LDA.

NICIE (Northern Ireland Council for Integrated Education) (1991) NICIE Statement of Principles. Belfast: Northern Ireland Council for Integrated Education.

Nussbaum, M.C. (1994) 'Patriotism and cosmopolitanism'. Boston Review, 1 October. Online. https://tinyurl.com/oy4mal8 (accessed 17 August 2019).

Nutbrown, C. and Clough, P. (2009) 'Citizenship and inclusion in the early years: Understanding and responding to children's perspectives on "belonging". International Journal of Early Years Education, 17 (3), 191-206.

Oxfam (2006) Education for Global Citizenship: A guide for schools. Oxford: Oxfam.

Scoffham, S. (2018) 'Global learning: A catalyst for curriculum change'. International Journal of Development Education and Global Learning, 10 (2), 135-46.

Simpson, J. (2017) '"Learning to unlearn" the charity mentality within schools'. Policy and Practice: A Development Education Review, 25, 88-108.

Tanswell, Z. (2011) 'Is It Possible to Change People's Behaviours and Attitudes through Global Learning?'. Unpublished MA thesis, University of Hertfordshire.

UKaid (2010) 'The Global Dimension in Schools Northern Ireland. Guidance for policymakers'. Commissioned by The Global Dimension in Schools Northern Ireland, funded by DFID. Online. https://tinyurl.com/yxk6jgau (accessed 16 September 2019).

UN (United Nations) (2002) 'In Yale University address, Secretary-General pleads cause of "inclusive" globalization'. Press release, 2 October. Online. www.un.org/press/en/2002/ SGSM8412.doc.htm (accessed 18 August 2019).

Worden, E.A. and Smith, A. (2017) 'Teaching for democracy in the absence of transitional justice: The case of Northern Ireland'. Comparative Education, 53 (3), 379-95. 